LWSA

Local Wisdom, Social, and Arts

PAPER - OPEN ACCESS

Hak Ekonomi Perempuan: Pekerja Rumahan dalam Jangkauan Undang-Undang Ketenagakerjaan

\author{
Author : Agusmidah Agusmidah \\ DOI $\quad: 10.32734 /$ lwsa.v1i1.133 \\ Electronic ISSN : :2654-7058 \\ Print ISSN : 2654-7066
}

Volume 1 Issue 1 - 2018 TALENTA Conference Series: Local Wisdom, Social and Arts

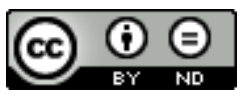

This work is licensed under a Creative Commons Attribution-NoDerivatives 4.0 International License.

Published under licence by TALENTA Publisher, Universitas Sumatera Utara
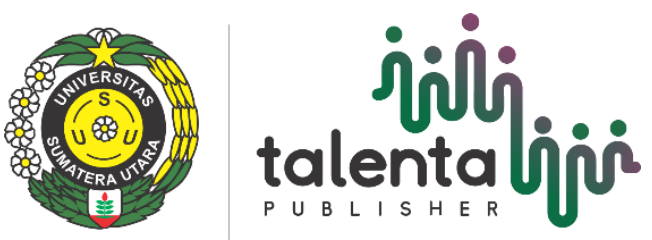


\title{
Hak Ekonomi Perempuan: Pekerja Rumahan dalam Jangkauan Undang-Undang Ketenagakerjaan
}

\author{
Agusmidah $^{\mathrm{a}}$ \\ ${ }^{a}$ Fakultas Hukum, Universitas Sumatera Utara, Medan-20155, Indonesia \\ midahagus@gmail.com
}

\begin{abstract}
Abstrak
Pekerja rumahan belum banyak dikenal dan keberadaannya tidak terlihat sebagai kelompok masyarakat produktif, bahkan data statistik tidak mengkategorikan perempuan pekerja rumahan sebagai golongan pekerja, tetapi sebagai ibu rumah tangga. Informalisasi pekerja rumahan berdampak pada kondisi kerja yang tidak menguntungkan, upah rendah, tidak ada kontrak kerja, tidak ada jaminnan sosial, jam kerja panjang, rentan atas resiko kecelakaan kerja, dsb. Tulisan ini dimaksud dapat menjawab persoalan hukum atas perlindungan pekerja rumahan, menggunakan data sekunder, dengan pendekatan perundang- undangan namun tetap diisi kajian sosiologi dan antropologi. Hasil penelitian menunjukkan kaburnya status hubungan kerja pekerja rumahan menyebabkan hilangnya sejumlah hak pekerja, dan keadaan ini merupakan dampak dari fleksibilitas hubungan kerja. Pemerintah tidak bisa menghilangkan tanggungjawab pengawasan dan perlindungan meskipun sektor informal belum tercakup sebanyak sektor formal dalam UU Ketenagakerjaan.
\end{abstract}

Kata kunci: Pekerja Rumahan; Hak Ekonomi Perempuan; UU Ketenagakerjaan

\section{Pendahuluan}

Pekerja rumahan atau pekerja berbasis rumah merupakan bagian dari putting out system yang ada dalam produksi. Pelaku usaha menerapkan bentuk subkontrak untuk kegiatan industrinya dengan satu alasan yaitu meminimalkan ongkos produksi, dengan tidak mengurangi produktifitas tentunya. Ini merupakan cara mudah dan fleksibel untuk memenuhi permintaan yang fluktuatif dan sebagai sarana untuk menggantikan biaya overhead manakala menggunakan pekerja standar. Sistem ini membantu perusahaan mengurangi investasi untuk ruang kerja tambahan, juga efektif mengalihkan biaya produksi dan resiko serta tanggungjawab atas kualitas produk pada pribadi pekerja rumahan.

Sisi pengusaha atau pemberi kerja menggunakan model pekerja rumahan dimana bekerja dari rumah mereka atau tempat lain selain perusahaan bahkan jaraknya bisa jauh dari lokasi perusahaan, memiliki beberapa tantangan. Pertama, rumitnya pengaturan untuk mempekerjakan pekerja serta kurangnya pengawasan langsung terhadap kinerja para pekerja rumahan. Kedua, sifat sementara atau musiman dari pekerjaan yang dilakukan oleh pekerja rumahan menjadi kendala memenuhi tanggung jawab hukum mereka. (Apindo \& ILO, 2013). Kekuatan posisi tawar pengusaha atau pemberi kerja jauh lebih menguntungkan dibanding para pekerja rumahan yang notabene berpendidikan rendah.

Banyak perempuan di pelosok tanah air kita merupakan kategori pekerja. Sayangnya mereka tidak terlihat sebagai pekerja yang lazim yang dapat menyebutkan lokasi kerja atau lokasi perusahaan pada siapa yang bertanya, tidak pula tercatat namanya dalam dokumen perusahaan sebagai salah satu penerima upah, juga tidak menerima tunjangan 
lainnya secara teratur, apalagi menerima THR (tunjangan hari raya) menjelang hari besar keagamaan. Ya, itulah yang dialami oleh perempuan sebagai pekerja berbasis rumah atau pekerja rumahan yang saat ini makin mudah ditemukan. Data yang diperoleh di satu kabupaten di provinsi Sumatera Utara sebanyak 444 (empat ratus empat puluh empat) orang adalah perempuan, hanya ada 2 (dua) orang laki-laki dari total 446 (empat ratus empat puluh enam) orang. (Bitra, 2016). Mayoritas pekerja rumahan adalah perempuan juga ditemukan di negara Chili, India, Filipina, dan Thailand [3]

Umumnya perempuan menjadi mayoritas dalam pekerja rumahan karena waktu kerja dan situas i kerja yang dapat disesuaikan dengan tugas di rumah tangga. Dampak yang timbul kemudian adalah apa yang dilakukan perempuan pekerja rumahan dianggap sebagai pekerjaan sampingan, mengisi waktu luang, bukan sebagai kegiatan inti, sehingga upah yang diberikan dibawah standar, jam kerja tidak terbatas, resiko kesehatan dan keselamatan kerja, tidak ada kontrak kerja, dan tidak ada jaminan sosial. Kemiskinan sangat dekat dengan pekerja rumahan, apalagi mereka tidak memiliki daya tawar terhadap perusahaan [6].

Paparan di atas mengantarkan pada persoalan hukum bagaimana memberi perlindungan hukum pada pekerja rumahan yang kedudukannya ditempatkan sebagai pekerja sektor informal? Tulisan ini mencoba mengurai kekosongan hukum dari pekerja rumahan yang belum disentuh peraturan perundangan ketenagakerjaan sehingga dapat mendistorsi hak ekonomi pekerja (perempuan) yang secara real bekerja dan memberi kontribusi besar bagi pengusaha dalam melakukan produksi barang yang bernilai ekonomi bagi perusahaan. Metode yang digunakan adalah normatif empiris dengan pendekatan konsep dan perudang-undangan. Bahan hukum diperoleh dari studi kepustakaan dan kuesioner serta wawancara yang dilakukan terhadap responden pekerja rumahan di Kota Medan dan Kabupaten Deli Serdang.

\section{Pembahasan}

\subsection{Kurangnya popularitas pekerja rumahan}

Banyak yang tidak memahami dan bahkan belum pernah mendengar istilah pekerja rumahan, dan menyamakannya dengan pekerja rumah tangga atau asisten rumah tangga, padahal ini berbeda. Pengertian dari kerja rumahan dapat dirujuk dalam Konvensi ILO No. 177 Tahun 1996 tentang Kerja Rumahan. Pasal 1 konvensi menyebutkan kerja rumahan adalah pekerjaan yang dikerjakan seseorang, yang kemudian disebut sebagai pekerja rumahan (i) di dalam rumahnya atau di tempat lain pilihannya, selain tempat kerja pemberi kerja; (ii) untuk mendapatkan upah; (iii) yang menghasilkan suatu produk atau jasa sebagaimana yang ditetapkan oleh pemberi kerja, terlepas dari siapa yang menyediakan peralatan, bahan atau input lain yang digunakan, kecuali orang ini memiliki derajat otonomi dan kemandirian ekonomi yang diperlukan untuk dianggap sebagai pekerja mandiri menurut undang-undang, peraturan atau putusan pengadilan nasional.

Dua kategori dasar pekerja berbasis rumahan yang dikemukakan oleh Emma Ellen dkk (2015) setelah melakukan penelitian pemetaan pekerja rumahan di Indonesia adalah:

"pertama, pekerja berbasis rumahan mandiri menanggung seluruh resiko menjadi operator mandiri. Mereka membeli sendiri bahan baku, persediaan, dan peralatan, dan membayar biaya utilitas dan transportasi. Mereka menjual sendiri barang jadi mereka, utamanya ke pelanggan dan pasar lokal tetapi kadang-kadang ke pasar internasional. Sebagian besar tidak mempekerjakan orang lain tetapi mungkin memiliki anggota keluarga tidak dibayar bekerja dengan mereka. Kedua, pekerja berbasis rumahan sub-kontrak (disebut pekerja rumahan) dikontrak oleh pengusuha, perorangan atau perusahaan, seringkali melalui perantara. Mereka biasanya diberi bahan baku dan dibayar per satuan. Mereka biasanya tidak menjual barang jadi. Namun mereka sesungguhnya menanggung banyak biaya produksi: tempat kerja, peralatan, persediaan, utilitas, dan transportasi. Pekerja rumahan bukan pekerja rumah tangga yang bekerja di atau untuk rumah tangga melaksanakan tugas-tugas kerumahtanggaan. Mereka juga berbeda dengan pekerja berbasis rumah mandiri yang bekerja di rumah secara mandiri [2].

Indonesia dalam peraturan perundangan ketenagakerjaan belum ada menyebutkan istilah pekerja rumahan, maka definisi yang akan digunakan adalah yang terdapat dalam KILO No. 177 Tahun 1999 sebagaimana di sebutkan di atas. 
Definisi menyebutkan melakukan pekerjaan di tempat lain selai tempat kerja milik pemberi kerja, harus dimaknai bukan sebagai pekerja mandiri (swapekerja) dan bukan pekerja yang melaksanakan pekerjaan mereka sebagai pegawai perusahaan di rumah.

Pekerja mandiri atau swapekerja dalam buku Iman Supomo (1995) dimaknai sebagai pekerja yang melakukan pekerjaan secara bebas, tidak terikat dalam hubungan kerja atasan dan bawahan, keuntungan dan kerugian menjadi tanggungannya sendiri, pekerja mandiri memiliki kemampuan mengakses pasar secara langsung. Artinya tingkat otonomi dan kemandirian swa pekerja sangatlah tinggi. Berbeda dengan pekerja rumahan, meski bekerja di rumah atau tempat lain yang bukan lokasi kerja perusahaan, namun tidak memiliki kemandirian atau derajat otonomi, tidak dapat mengakses pasar secara langsung, keuntungan ekonomi hanya berharap penuh dari upah yang diberikan oleh pemberi kerja.

Hal lain yang menyebabkan pekerja rumahan belum populer dalam masyarakat Indonesia adalah langkanya data statistik yang memperlihatkan keberadaan mereka secara sosial ekonomi. Statistik angkatan kerja nasional (Sakernas) belum mengidentifikasikan pekerja berbasis rumah di Indonesia, demikian juga survei industri tidak mampu menangkap keberadaan mereka dan semakin membuat pekerja rumahan tidak terlihat dan menjadi bagian dari pekerja produktif. Keadaan ini timbul dikarenakan pekerja rumahan bukanlah jenis pekerja formal, melainkan pekerja informal.

\subsection{Pekerja informal sebagai gejala meningkatnya fleksibilitas ketenagakerjaan}

Gejala informalisasi sektor pekerjaan merupakan strategi global yang dijalankan pemberi kerja demi mencapai tingkat efisiensi dengan produktifitas tinggi. Rantai pasokan global yang kompleks didorong oleh persaingan untuk produksi murah, praktik mensubkontrakkan produksi kepada pekerja rumahan tumbuh signifikan dalam industri manufaktur. Pekerja rumahan berada pada ujung rantai pasokan yang panjang dan dinamis. Informalitas sektor pekerja rumahan membuat kabur taggung jawab pemberi kerja utama.

Maraknya model kerja ini disebabkan salah satunya oleh fenomena ekonomi global yang dikenal sebagai trend fleksibilitas tenaga kerja. Fleksibilitas tenaga kerja memberi ruang gerak lebih luas pada pengusaha untuk mengurangi penggunaan tenaga kerja standar, mempekerjakan pekerja secara lepas (casualisation of labour), subkontrak dan atau alih daya. Mengubah pola kerja kepada tujuan efisiensi, dengan tetap menciptakan daya saing perusahaan agar mampu merespon setiap fluktuasi dan kecenderungan pasar.

Iklim Fleksibilitas yang juga merasuki Indonesia ini berkembang dan subur dikarenakan kondisi ketenagakerjaan dalam negeri yang tidak menguntungkan. Surplus tenaga kerja, dan minus lapangan kerja. Badan Pusat Statistik (BPS) mencatat pengangguran di Indonesia menembus angka 7,4 juta jiwa pada Februari tahun 2015, angka ini bertambah sebanyak lebih dari 300 ribu jiwa dibanding tahun sebelumnya (2014) hal ini disebabkan antara lain melambatnya ekonomi nasional. Perlambatan ekonomi Indonesia dibuktikan dengan rendahnya angka pertumbuhan ekonomi Indonesia kuartal I/2015 sebesar 4,71\% atau melambat dibanding triwulan I/2014 (Sindo News).

Pekerja rumahan adalah salah satu bentuk fleksibilitas tenaga kerja, yang oleh banyak penelitian, di antaranya yang disponsori oleh ILO (Internasional Labor Organization) tidak hanya melibatkan perusahaan dalam negeri namun ada juga melibatkan rantai ekonomi internasional yang sangat kompleks. [6]. Karakteristik pekerja rumahan antara lain tidak adanya perjanjian kerja secara tertulis, sifat pekerjaan tidak tetap, upah ditetapkan secara absolut oleh pemberi kerja tanpa ada nilai tawar dari pekerja, kriteria dan standar mutu ditetapkan, kerusakan barang menjadi tanggungjawab pekerja, biaya produksi ditanggung pekerja (listrik, lilin, gunting, dll), jam kerja tidak tentu bahkan sangat panjang tanpa ada perhitungan upah lembur.

Membahas tentang sektor pekerja informal menjadi menarik berdasar alasan yang ditulis oleh Suahasil Nazara (2010) bahwa mempertimbangkan peran ekonomi informal dalam proses pembangunan, setidaknya ada sejumlah pertanyaan penting yang bisa diurai dari perekonomian informal ini, yaitu: apakah keberadaan ekonomi informal merupakan sumber keprihatinan atau justru merupakan cara lain untuk menciptakan lapangan kerja dalam sebuah perekonomian yang sedang berkembang?; apakah ekonomi informal didorong oleh tekanan, pilihan, atau tekanan dan pilihan?; serta sejauh mana pekerja ekonomi informal terkena dampak krisis keuangan dan ekonomi global?. Terkait 
dengan tema besar tulisan ini adalah pekerja rumahan terkategori sebagai pekerja sektor informal yang dengan mudahnya orang akan berkata belum ada peraturan ketenagakerjaan yang mengatur perlindungannya.

\subsection{Kondisi sosiologis pekerja rumahan}

Sejumlah penelitian yang dilakukan di Pulau Jawa, dan Sumatera dapat diakses dalam situs ILO menjadi rujukan sosiologis betapa mendesaknya kebutuhan kaum pekerja rumahan akan instrumen perundang-undangan yang dapat dijadikan landasan bagi perlindungan hak-hak mereka. Hak tersebut mencakup hak atas status hubungan kerja yang jelas, hak ekonomi (antara lain upah dan jaminan sosial), hak sosial (jam kerja dan situasi kerja layak), dan hak atas kesehatan dan keselamatan kerja.

Beberapa Lembaga Swadaya Masyarakat (LSM) digandeng oleh ILO melalui Proyek MAMPU-Akses ke Lapangan Kerja dan Pekerjaan Layak bagi Perempuan berupaya mendorong melalui pemerintah daerah agar pekerja rumahan diatur dalam bentuk Perda. Sumatera Utara salah satunya dimotori oleh Yayasan Bitra Indonesia bersama beberapa Serikat Pekerja saat ini giat mendorong DPRD provinsi agar memasukkan usulan Perda Pekerja Rumahan dalam prolegda pada kesempatan pertama, diharapkan paling lambat di 2016 usulan perda ini akan dapat dibahas.

Kesulitan mengatur perlindungan pekerja rumahan menggunakan payung hukum UU Ketenagakerjaan No. 13 Tahun 2003 sudah dijelaskan di atas menemukan kendala normatif yaitu tidak terpenuhinya unsur-unsur dasar hubungan kerja yang jelas karena hubungan kerja merupakan landasan utama munculnya hak dan kewajiban hukum para pihak. Ini terjadi karena UUK masih membatasi diri mengatur sektor pekerja formal saja, yaitu pekerja dengan hubungan kerja yang standar. Mengatasinya adalah dengan menggunakan dasar fundamental dan konstitusional.

Secara fundamental Indonesia adalah negara hukum yang berideologi Pancasila dengan lima nilai dasar yang menjadi sumber hukum materil dalam pembuatan peraturan perundang-undangan. Sila kelima menyatakan keadilan sosial bagi seluruh rakyat Indonesia. Keadilan sosial sekaligus menjadi tujuan hidup bernegara Indonesia (Alinea keempat UUD RI Tahun 1945). Tambahan lagi dalam konstitusi kita Pasal 27 UUD RI Tahun 1945 pada ayat 1 dan 2 jelas menyebutkan bahwa setiap warga negara memiliki kedudukan sama dalam hukum dan pemerintahan, sehingga memilah perlindungan hukum kerja hanya untuk pekerja formal saja sangat tidak bersesuaian dengan amanat Pancasila dan UUD negara RI.

Membiarkan sektor kerja informal tanpa aturan yang jelas dan tegas merupakan tindakan pembiaran dan melestarikan kemiskinan bagi masyarakat marginal. Hal ini dikarenakan sektor informal rentan atas upah murah, tidak ada jaminan sosial, jam kerja panjang, tanpa K3, dan bahkan ketidakpastian atas keberlanjutan kerja itu sendiri. Keberadaan ekonomi informal umumnya dilihat sebagai sumber keprihatinan, sebagai keadaan setengah menganggur dan kemiskinan [8]. Sumber penelitian yang sama mengemukakan bahwa Informalitas dalam ekonomi merupakan akibat dari peraturan pasar tenaga kerja yang menuntut perlindungan terhadap upah dan kondisi kerja pekerja sektor formal yang lebih tinggi. Adanya peraturan pasar tenaga kerja yang kaku, membuat pengusaha menghindari rekrutmen permanen dan oleh karenanya mendorong informalitas. Di saat bersamaan, pencari kerja akhirnya mencari pelarian ke sektor ekonomi informal saat mereka di hadapkan pada antrean panjang untuk memperoleh pekerjaan di sektor formal. Kondisi ini semakin marak dalam era industrialisasi dengan ideologi liberalisasi: mekanisme pasar bebas.

\subsection{Kendala normatif perlindungan pekerja rumahan dalam undang-undang ketenagakerjaan}

\subsubsection{Hubungan kerja}

Memaksakan kedudukan pekerja rumahan sama seperti pekerja dalam suatu hubungan kerja normal (baca: formal) yang diatur dalam UUK mungkin dapat dilakukan. Penulis tidak membantah bahwa pekerja rumahan adalah pekerja yang didefinisikan sebagai setiap orang yang bekerja dengan menerima upah atau imbalan dalam bentuk lain. Hal ini dikarenakan unsur yang dimaksud dalam pasal tersebut yaitu setiap orang, dan unsur bekerja dengan menerima upah atau imbalan dalam bentuk lain memang terpenuhi. Bagaimana dengan unsur hubungan kerja? Apakah semua unsur dalam hubungan kerja dapat dipenuhi?

Hubungan kerja dirumuskan dalam Pasal 1 angka 15 UUK sebagai hubungan antara pengusaha dengan pekerja/buruh berdasarkan perjanjian kerja, yang mempunyai unsur pekerjaan, upah, dan perintah. 
Pekerja rumahan jelas memenuhi unsur adanya pekerjaan, dan pekerjaan yang dilakukan tersebut melahirkan hak dan kewajiban yaitu pembayaran upah, bagaimana dengan unsur perintah? Dan bagaimana dengan perjanjian kerja yang mengawali hubungan kerja?.

Unsur perintah menjadi sangat kabur sehingga menyamarkan hubungan kerja dalam kerja rumahan ini. Kekaburan tersebut memang suatu yang sengaja diciptakan. Lihatlah bahwa lapisan dalam rantai subkontrak sangatlah panjang dan kompleks, pekerja rumahan adalah ujung dari rantai itu. Perantara atau agen dalam sistem ini bukan seperti yang dikehendaki UUK, yang mensyaratkan harus berbadan hukum. Perantara atau agen bisa perorangan, baik memiliki hubungan kerja dengan perusahaan maupun tidak (bahkan di antaranya adalah preman). Berikutnya adalah unsur Perintah yang menjadi ciri khas dalam hubungan kerja majikan-buruh di mana menunjukkan adanya sub ordinasi, hubungan diperatas. Perintah diwujudkan dalam bentuk adanya instruksi kerja (peraturan perusahaan atau standart operasional prosedur) yang harus dipenuhi pekerja atau buruh, konsekwensi dari tidak dijalankannya perintah akan berdampak terhadap hak dan kewajiban kedua belah pihak. Tanpa ada perintah, seseorang bekerja layaknya pekerja mandiri: bekerja kapan saja saat ia mau, tidak terikat jam kerja, lokasi kerja ditentukan sendiri, namun tidak memiliki akses langsung terhadap pasar, jadi untuk menyamakan pekerja rumahan dengan pekerja mandiri juga tidaklah mungkin.

Praktek pekerja rumahan pada kenyataannya tidak diawali dengan perjanjian kerja (tertulis), meski dimungkinkan adanya perjanjian kerja lisan, namun dengan panjangnya lapisan dan rantai antara pengusaha dengan pekerja rumahan menghilangkan unsur perjanjian kerja dan perintah ini.

Kekaburan hubungan kerja dalam sistem pekerja rumahan tidak menjadi soal bagi pengusaha atau pemberi kerja, tidak demikian harusnya bagi pekerja, sebab akan kaburlah bahkan hilang hubungan hak dan kewajiban. Kondisi ini tidak dapat dibiarkan oleh pemerintah, mengingat pekerja rumahan adalah bagian penting dalam proses produksi. Pekerja rumahan sesungguhnya ikut berperan menggerakkan pertumbuhan ekonomi, dan meningkatkan kemampuan daya beli/ konsumsi rumah tangga.

\subsubsection{Kedudukan perantara tidak sama dengan penerima pekerjaan (alih daya)}

Sub kontrak dalam bentuk pengalihan pekerjaan pada pihak lain dikenal dalam UUK, syaratnya jelas bahwa penerima kerja adalah badan hukum yang akan menyelesaikan pekerjaan dengan mempekerjakan pekerja di bawah perintahnya. Halnya dalam pekerja rumahan (putting out system) ada perantara yang menghubungkan pemberi kerja dengan pekerja rumahan. Para perantara kebanyakan adalah orang perorangan dan tidak memiliki kontrak kerja dengan pemberi kerja utama maupun dengan pekerja. Mereka mendapatkan fee bisa dari pemberi kerja, bisa juga dari pekerja rumahan. Adanya perantara menyebabkan pekerja tidak berinteraksi langsung dengan pemberi kerja, termasuk dalam hal upah, sebab perantaralah yang membayar sesuai dengan cara yang disepakati, perantara pula yang melakukan kontrol atas kualitas kerja dan akan memberi sanksi bila pekerjaan tidak sesuai ketentuan yang telah diberikan oleh si perantara.

Sub kontrak atau alih daya dalam UUK terbagi atas perjanjian pemborongan kerja dan perjanjian penyediaan jasa pekerja atau buruh. Kedua jenis perjanjian ini selain harus memenuhi syarat dilakukan oleh badan hukum juga harus digunakan untuk jenis pekerjaan penunjang, bukan pekerjaan inti. Akan halnya pekerja rumahan banyak didapati mengerjakan pekerjaan yang berkontribusi atas proses produksi, misalnya produksi sepatu, produksi sendal karet, produksi kawat pemanggang ikan, dan lain-lain. Dalam hal produksi kawat pemanggang ikan, pekerja rumahan malahan menjadi pekerja utama, oleh karena melakukan penganyaman kawat, dari bahan batangan kawat menjadi anyaman sempurna, jelas itu adalah pekerjaan inti.

Jelas bahwa kedudukan hukum dari perantara dalam pekerjaan rumahan tidak sama dengan perusahaan pemborong, namun apakah bisa disamakan sebagai pemberi kerja. Pasal 1 angka 4 UUK No 13 tahun 2003 menyatakan: "Pemberi kerja adalah orang perseorangan, pengusaha, badan hukum, atau badan-badan lainnya yang mempekerjakan tenaga kerja dengan membayar upah atau imbalan dalam bentuk lain." Perantara adalah perseorangan, dan ia pun membayarkan upah atau imbalan pada pekerja rumahan. Pertanyaan normatif akan muncul, apakah perantara bertanggung jawab atas hak-hak pekerja? Jelas tidak. Sekali lagi meski terkesan tendensius inilah keberhasilan rezim 
kapitalis dengan mengaburkan status hubungan kerja, karena hubungan kerja berkorelasi dengan tanggung jawab hukum, hak dan kewajiban hukum.

\subsection{Perjanjian kerja}

Pasal 1 angka 14 UUK menyatakan: "Perjanjian kerja adalah perjanjian antara pekerja/buruh dengan pengusaha atau pemberi kerja yang memuat syarat-syarat kerja, hak, dan kewajiban para pihak." Rumusan ini menetapkan bahwa pembuat perjanjian kerja adalah pekerja/buruh dengan pengusaha atau pemberi kerja.

Ada dua bentuk perjanjian kerja, yaitu perjanjian yang dibuat secara lisan dan secara tertulis (Pasal 50 UUK). Diatur bahwa perjanjian secara lisan hanya dibenarkan untuk jenis pekerjaan yang terus menerus atau disebut Perjanjian Kerja Waktu Tidak Tertentu (PKWTT), sedangkan perjanjian yang berjangka waktu (PKWT) harus dibuat secara tertulis (Pasal 57 ayat (1)). Sulit menyatakan ada perjanjian kerja dalam kerja rumahan yang dibuat secara lisan oleh karena pemberi kerja berada pada level yang tidak terjangkau pekerja rumahan, secara langsung quality control atas hasil kerjapun dilakukan oleh perantara yang bukan pemberi kerja, bukan pula penerima kerja, bukan perusahaan sub kontraktor.

\subsection{Pengawasan kerja dan perlindungan kerja}

Hal yang paling mendasar yang perlu dilakukan pengawasan terhadap pekerja rumahan adalah jam kerja yang panjang, ini terjadi karena mereka berupaya mencapai produktifitas tinggi dengan waktu yang singkat (karena upah dibayar per satuan hasil). Alhasil pekerjaan dilakukan sepanjang hari, melebihi batas kerja manusia yang telah ditentukan yaitu maksimal 8 jam sehari dengan penambahan kerja lembur maksimal 3 sampai 4 jam sehari. Dampak dari keadaan ini menambah besar peluang terjadinya kecelakan kerja apalagi cara kerja dan tempat kerja yang tidak memenuhi standar kesehatan dan keselamatan kerja (K3).

K3 juga menjadi poin perhatian tersendiri. Pekerja rumahan umumnya menjadikan rumah tempat tinggalnya sekaligus sebagai tempat kerja, barang yang dia terima dari produsen sebagian merupakan paparan zat kimia, seperti misalnya sendal karet (swallow), sedikit banyaknya pasti mempengaruhi udara di dalam rumah tersebut, belum lagi asap lilin dan bau bakaran plastik dari pengemasan sedotan, dan lain-lain. Semakin rentanlah pekerja rumahan mengalami resiko kerja.

Pengawasan yang juga perlu dilakukan adalah banyaknya keterlibatan anak, ini juga terjadi karena keinginan mencapai hasil produksi yang maksimal dalam waktu yang singkat. Memang keterlibatan seluruh anggota keluarga sering kali dilakukan, namun bila hal tersebut melibatkan anak dan dapat mengganggu kewajiban dan hak anak untuk sekolah dan bermain maka secara tidak langsung ada pelanggaran terhadap hak anak.

Perlindungan kerja rumahan semakin mendesak mengingat semakin meluasnya cara kerja fleksibilitas, kondisi pasar tenaga kerja yang tidak menguntungkan: tingginya angkatan kerja, rendahnya lapangan kerja, keahlian dan tingkat pendidikan rendah, jangan sampai muncul perbudakan gaya baru lagi.

\subsection{Pekerja rumahan: rentannya daya tawar perempuan untuk akses ekonomi}

Proyek ILO MAMPU mengadakan penelitian dan menemukan karakteristik pekerja rumahan mayoritas berjenis kelamin perempuan. Data BPS menunjukkan partisipasi angkatan kerja perempuan umumnya rendah di semua provinsi di Indonesia, salah satunya disebabkan faktor tugas perawatan rumah tangga. Kemiskinan, menjadi pendorong masuknya mereka ke pekerja rumahan karena kebutuhan menghasilkan pendapatan tambahan untuk rumah tangga [2].

Pekerjaan rumahan yang tidak membutuhkan keahlian tinggi, membuat perempuan dengan tingkat pendidikan rendah dapat melakukan pekerjaan dengan baik. Umumnya kondisi ini ditunjang oleh keadaan para suami yang juga berpenghasilan rendah, sebagian di antaranya bekerja jauh dari tempat asalnya (migrasi). Ini menunjukkan adanya kesadarn perempuan atas tanggungjawab dan usaha untuk berkontribusi terhadap kelangsungan ekonomi keluarga.

Penelitian juga mengungkap bahwa masuknya perempuan ke pekerjaan rumahan dilakukan setelah anak-anak mulai bersekolah, ada pula yang masuk ke pekerja rumahan karena 'warisan' dari keluarga mereka, ada pula yang 
mulai bekerja setelah menikah dan anak pertama meraka telah berusia 2 tahun. Ternyata kegiatan ekonomi perempuan pekerja rumahan juga dilakukan bersamaan dengan kegiatan ekonomilainnya seperti menjaga kios/toko, menerima jasa binatu, mengumpulkan tanaman bumbu dan sayuran untuk dijual, jasa kebersihan, dan peternakan.

Secara keseluruhan realita ini menunjukkan bahwa posisi tawar perempuan untuk mengakses hak ekonomi secara penuh sangatlah rendah. Ini juga ditunjukkan oleh adanya penelitian lain yang membuat peta keberadaan perempuan dalam bentuk hierarki penghasilan dan resiko kemiskinan perempuan sangatlah besar di banding laki-laki.

Memberdayakan pekerja rumahan mutlak dilaksanakan oleh pemerintah, mengingat Undang-undang Ketenagakerjaan (UUK) pada Pasal 4 mengenai tujuan pembangunan ketenagakerjaan menyebutkan bahwa pembangunan ketenagakerjaan dilakukan untuk: a. memberdayakan dan mendayagunakan tenaga kerja secara optimal dan manusiawi; b. mewujudkan pemerataan kesempatan kerja dan penyediaan tenaga kerja yang sesuai dengan kebutuhan pembangunan nasional dan daerah; c. memberikan perlindungan kepada tenaga kerja dalam mewujudkan kesejahteraan; dan d. meningkatkan kesejahteraan tenaga kerja dan keluarganya.

\section{Penutup}

Pekerja rumahan dikategorikan sebagai pekerjaan sektor informal. UUK yang ada sayangnya belum mencakup bagaimana mekanisme pengawasan dan perlindungannya secara ketat. Kedudukan perempuan dalam sektor informal di Indonesia menempati porsi terbesar dibanding laki-laki. Hal ini mengukuhkan adanya posisi rentan perempuan sebagai pekerja bergaji rendah, tidak memiliki daya tawar, dianggap sebagai pencari nafkah sampingan. Kendala normatif dalam upaya perlindungan pekerja rumahan adalah adanya kekaburan status hubungan kerja yang didefinisikan dalam UU Ketenagakerjaan. Tidak adanya unsur perintah, biasnya pihak pemberi kerja atau pengusaha, dikarenakan lapisan dan rantai produksi yang panjang mengakibatkan kewajiban hukum ketenagakerjaan dari pengusaha atau pemberi kerja terhadap pekerja rumahan menjadi tidak ada. Akibatnya perempuan pekerja rumahan digaji murah, tidak terjamin kelangsungan kerja, tidak ada kontrak kerja yang jelas, tidak ada jaminan sosial dan perlindungan $\mathrm{K} 3$.

Perlu dilakukan kajian mendalam melibatkan berbagai institusi termasuk perguruan tinggi untuk merumuskan model dan norma perlindungan yang tepat bagi pekerja rumahan sebagai bagian dari sumber daya manusia yang memiliki kontribusi dalam proses produksi, sehingga hak ekonominya patut untuk dilindungi. Nantinya perguruan tinggi dapat memberi masukan tersebut pada pemerintah daerah selaku otoritas yang bertanggungjawab melaksanakan pembangunan sektor ketenaga kerjaan sebagaimana diamanahkan oleh UU Pemerintahan Daerah.

\section{Referensi}

[1] BAPPENAS. 2013. Buku Pegangan Perencanaan Pembangunan Daerah 2014, Kementerian Perencanaan Pembangunan Nasional, Badan Perencanaan Pembangunan Nasional.

[2] Emma Ellen dkk.2015. Pekerja Rumahan Indonesia Hasil Penelitian Pemetaan Pekerja Rumahan di Sumatera Utara, Jawa Barat, Jawa Tengah, Yogyakarta, Jawa Timur dan Banten, ILO Jakarta.

[3] ILO. 2015. Pekerja Berbasis Rumahan: Kerja Layak dan Perlindungan Sosial Melalui Organisasi dan Pemberdayaan: Pengalaman, praktik baik dan pelajaran dari pekerja berbasis rumahan dan organisasi mereka, ILO Jakarta, Jakarta.

[4] Mengenal Pekerja Rumahan, Brosur.

[5] Konvensi ILO Nomor 177 Tahun 1999 Kerja Rumahan.

[6] Miranda Fajerman. 2014. Tinjauan Kerangka Peraturan Perundang-undangan untuk Pekerja Rumahan di Indonesia 2013, ILO Jakarta.

[7] Rekomendasi ILO Nomor 184 Tahun 1999 Kerja Rumahan.

[8] Suahasil Nazara. 2010. Ekonomi Informal di Indonesia: Ukuran, Komposisi dan Evolusi, ILO Jakarta.

[9] UU No. 13 Tahun 2003 Tentang Ketenagakerjaan, Lembaran Negara Nomor 39 tahun 2003 Tambahan Lembaran Negara Nomor 4279

[10] Yayasan Bitra Indonesia.2016. Kertas Posisi Urgensi Peraturan Daerah Perlindungan Pekerja Rumahan di Sumatera Utara 